\title{
EFFICIENCY OF THE GYNECOLOGIC MALIGNANCIES IDENTIFICATION MEASURES AT THE LEVEL OF PRIMARY HEALTH CARE
}

Bochkova $A G^{1} \otimes$, Domozhirova $A^{2}$, Aksenova IA ${ }^{1,3}$

${ }^{1}$ South Ural State Medical University, Chelyabinsk, Russia

${ }^{2}$ Russian Scientific Center of Roentgenoradiology, Moscow, Russia

${ }^{3}$ Clinical Center of Oncology and Nuclear Medicine of Chelyabinsk Region, Chelyabinsk, Russia

\begin{abstract}
In Russia, for more than 10 years, within the framework of national projects, the activities have been carried out aimed at restructuring of the primary and specialized (including high-tech) medical care, as well as strengthening of primary health care directed at early detection of malignant neoplasms. The study was aimed to evaluate the effectiveness of the patient examination rooms for women in improvement of the adjusted cumulative survival of patients with gynecologic malignancies detected actively in 2005-2015 in the Chelyabinsk Region. Using the Population Based Cancer Registry (PBCR) of the Chelyabinsk Region database, the adjusted cumulative survival calculation for patients with cervical cancer (389), uterine corpus cancer (373) and ovarian cancer (161) detected actively in the patient examination rooms of the Chelyabinsk Region (treatment group), as well as for cervical cancer (395), uterine corpus cancer (380) and ovarian cancer (163) detected in patients who sought medical assistance (control group), was performed for the first time. The staging of cervical cancer detected in the examination rooms in 2010-2017 was characterized by the high proportion of I/II stage tumors compared with the rest of patients' population of the Chelyabinsk Region (an average of 50.8 and $46.1 \%$ respectively). For uterine corpus cancer the average proportion was 85.5 and $82.0 \%$ respectively, and for ovarian cancers it was 42.0 and $37.4 \%$ respectively. Analysis of the PBCR of the Chelyabinsk Region for a 10-year period revealed the 5-year adjusted cumulative survival improvement in the actively detected cervical cancer patients compared to the control group (62.3 and $55.8 \%)$ respectively $(p=0.11)$. In patients with uterine corpus cancer, it was $82.0 \%$ for the main group and $70.4 \%$ for the control group $(p=0.001)$. In ovarian cancer patients, no significant differences in the 5 -year adjusted cumulative survival were observed ( $47.5 \%$ in the main group, $43.2 \%$ in the control group) $(p=0.49)$. Thus, the patient examination rooms are the effective model of the cancer secondary prevention available in the Chelyabinsk Region.
\end{abstract}

Keywords: gynecologic malignancies, early detection, patient examination rooms, secondary prevention of cancer

Author contribution: Bochkova AG — research planning, manuscript writing, data acquisition, data analysis and interpretation, literature analysis; Domozhirova AS — research planning, data analysis and interpretation, manuscript editing; Aksenova IA — data acquisition, manuscript writing.

Compliance with ethical standards: the study was approved by the Ethics Committee of South Ural State Medical University (protocol № 9 dated November 8, 2018).

$\triangle$ Correspondence should be addressed: Anna G. Bochkova

Dovatora, 23, Chelyabinsk, 454091; annabochkova7496@mail.ru

Received: 23.12.2019 Accepted: 08.01.2020 Published online: 22.01.2020

DOI: $10.24075 /$ brsmu.2020.003

\section{ОЦЕНКА ЭФФЕКТИВНОСТИ ПУТЕЙ ВЫЯВЛЕНИЯ ОПУХОЛЕЙ ЖЕНСКИХ ПОЛОВЫХ ОРГАНОВ НА УРОВНЕ ПЕРВИЧНОГО ЗВЕНА ЗДРАВООХРАНЕНИЯ}

\author{
А. Г. Бочкова ${ }^{1 凶}$, А. С. Доможирова ${ }^{2}$ И. А. Аксенова ${ }^{1,3}$ \\ ${ }^{1}$ Южно-Уральский государственный медицинский университет, Челябинск, Россия \\ ${ }^{2}$ Российский научный центр рентгенорадиологии, Москва, Россия \\ з Челябинский областной клинический центр онкологии и ядерной медицины, Челябинск, Россия
}

\begin{abstract}
В России более 10 лет в рамках национальных проектов проводят мероприятия, направленные на преобразование первичной и специализированной, в том числе высокотехнологичной медицинской помощи, усиление роли первичного медико-санитарного звена в целях раннего выявления злокачественных новообразований (ЗНО). Целью исследования было оценить результативность работы женских смотровых кабинетов (СК) в улучшении показателей кумулятивной скорректированной выживаемости (СкВ) больных с ЗНО женских половых органов, выявленных активно с 2005 по 2015 гг. на территории Челябинской области (ЧО). На основе базы данных Популяционного ракового регистра (ПРР) ЧО впервые осуществлены расчеты показателей кумулятивной СкВ больных с ЗНО шейки матки (389), тела матки (373) и яичников (161), выявленных активно в СК 40 (основная группа), и случаи 3 НО шейки матки (395), тела матки (380) и яичников (163), выявленных в ходе самообращений пациенток (группа контроля). Стадийную структуру активно выявленных случаев ЗНО шейки матки в СК за период 2010-2017 г. характеризует большой удельный вес І-ІІ стадий по сравнению с остальной популяцией заболевших в 40 - в среднем 50,8 и 46,1\% соответственно, в отношении 3 НО тела матки - 85,5 и 82,0\% соответственно, для овариальных раков - в среднем 42,0 и 37,4\% соответственно. Анализ базы данных ПРР 40 за 10-летний период позволил установить увеличение 5-летней кумулятивной СкВ для больных с диагнозом ЗНО шейки матки, выявленных активно в СК по сравнению с контрольной группой - 62,3 и 55,8\% соответственно $(p=0,11)$. В отношении 3 НО тела матки $-82,0 \%$ в основной группе и 70,4\% в группе контроля $(p=0,001)$. У больных с ЗНО яичников достоверных различий в показателях 5-летней кумулятивной СкВ не отмечено - 47,5\% в основной и 43,2\% в группе контроля ( $p=0,49)$. Таким образом, СК - одна из эффективных организационных моделей вторичной профилактики рака на территории 40.
\end{abstract}

Ключевые слова: рак женских половых органов, раннее выявление, смотровые кабинеты, вторичная просилактика рака

Вклад авторов: А. Г. Бочкова - планирование исследования, подготовка рукописи, сбор данных, анализ и интерпретация данных, анализ литературы; А. С. Доможирова - планирование исследования, анализ и интерпретация данных, редактирование рукописи; И. А. Аксенова - сбор данных, подготовка рукописи.

Соблюдение этических стандартов: исследование одобрено этическим комитетом ЮУгМУ Минздрава России (протокол № 9 от 8 ноября 2018 г.).

$\bowtie$ Для корреспонденции: Анна Геннадьевна Бочкова

ул. Доватора, д. 23, г. Челябинск, 454091; annabochkova7496@mail.ru

Статья получена: 23.12.2019 Статья принята к печати: 08.01.2020 Опубликована онлайн: 22.01.2020

DOI: 10.24075/vrgmu.2020.003 
Malignant neoplasms are one of the main problems on the agenda of modern medicine, and the leading cause of mortality in developed and developing countries [1, 2]. The economic losses from cancer are due to the significant costs of welfare and social insurance associated with the high cost of treatment, preventive and rehabilitation measures, as well as the long and often persistent disability. Thus, malignant neoplasms can be considered an essential problem of modern society.

The largest part in the structure of oncological morbidity in women in the Russian Federation belongs to the reproductive system malignancies (38.9\%), a half of which are gynecologic malignancies.

In 2017 in Russia over 26,000 new cases of uterine corpus cancer (3rd place, 7.8\%), over 17,500 cases of cervical cancer (5th place, $5.3 \%$ ), and over 14,500 cases of ovarian cancer (9th place, $4.3 \%$ ) were registered [3].

Demographic shift, environmental and reproductive dissonance, general deterioration of women's health along with an increase in the frequency of reproductive system malignancies require targeted and urgent decision-making regarding the prevention, screening and early diagnosis of malignant neoplasms through the interdisciplinary interaction of different specialists.

In Russian Federation, the three-level model of medical care for cancer patients has been put into practice, and primary healthcare is the basic platform on which the preventive measures are implemented. The basis is being formed for developing a motivation for the people to preserve and maintain a good health aimed to reduce mortality and disability due to disease [4].

The reduction of mortality of visually detectable gynecologic malignancies entirely depends on the quality and timeliness of the primary diagnosis [5].

Created in the early 1960s, a powerful network of patient examination rooms proved its high efficiency in the active detection of malignant neoplasms more than once. Thus, the proportion of diagnosed cervical cancer in all registered patients in the 1960 s and 1970 s reached $40 \%$ [6].

The cost-effectiveness of routine check-ups was repeatedly analyzed. The analysis demonstrated that preventive measures, the identification and treatment of patients with precancerous diseases and early forms of cancer require significantly less public spending than the treatment of patients with overt malignancies [7].

The main task of the patient examination room for women is to conduct the routine check-up of all women (over 18), who contacted the medical organizations for the first time during the year for the early detection of visually detectable chronic, pretumor and tumor diseases. Externally localized tumors that can be detected during the routine check-up account for $30 \%$ of all malignant tumors in people of both sexes and almost $40 \%$ in women [8].

It is very important to make the check-ups in the patient examination rooms widespread. Thus, in populations where the screening quality and coverage were high, a significant reduction in the invasive cervical cancer patients was detected $[9,10]$.

In addition, it is necessary to understand that neither the modern equipment of the patient examination rooms, nor the high qualifications and experience of the conducting the checkup obstetrician would be able to provide high final results if the contingent of women to be examined is not determined, the frequency of check-ups is not established, the flow of visits is not regulated, and a system of additional examination and routing of identified patients is not mastered. Thus, the active position of the primary health care medical organizations heads, who understand the importance of the routine check-ups in the patient examination rooms and focus on the corresponding area development, becomes relevant.

The study was aimed to evaluate the increased survival rate of patients with gynecologic malignancies in the Chelyabinsk Region through the use of the effective cancer detection in the patient examination rooms.

\section{METHODS}

In our study we used the data on the patients newly diagnosed with the visually detectable gynecologic malignancies registered in the Population Based Cancer Registry (PBCR) of the Chelyabinsk Region database formed in 2005-2017, as well as the reports on the functioning of the patient examination rooms in the Chelyabinsk Region municipalities' health care institutions during the specified period.

The treatment group included 923 patients aged 20 and over, who were diagnosed actively with the malignant neoplasms in the Chelyabinsk Region patient examination rooms in 2005-2015. Moreover, the distribution in accordance with the tumor localization was as follows: cervical cancer was diagnosed in 389 (42.1\%) patients, uterine corpus cancer in 373 (40.4\%) patients, and ovarian cancer in 161 (17.4\%) patients respectively.

The control group included 938 patients aged 22 and over, who sought medical assistance and were diagnosed with the malignant neoplasms during the same period: cervical cancer was diagnosed in 395 (42.1\%) patients, while uterine corpus cancer and ovarian cancer in 380 (40.5\%) and 163 (17.4\%) patients respectively.

The studied group' randomization was performed by the stratometric selection using the totality of the main prognostic signs (age at the time of diagnosis, stage of the disease, tumor morphological structure) in accordance with listed below inclusion and exclusion criteria.

Inclusion criteria: 100\% morphologically verified cervical cancer cases, detected actively in the Chelyabinsk Region patient examination rooms (treatment group) or upon the patients' individual appointment requests (control group).

Exclusion criteria: multiple primary malignancy cases, except the cases of combination with the skin basal cell carcinoma; lack of information about the cancer detection circumstances; lack of information about the patient's condition at the end of the year; the status of patients departed to the other regions of the country (according to the PBCR of the Chelyabinsk Region).

In the treatment group with a verified cervical cancer diagnosis, patients with localized tumors prevailed (the total number of patients with the I/II-stage cancer was 199 (51.2\%), and in the control group it was $199(50.4 \%))(p>0.05)$ (Table 1).

The stage distribution of the new uterine corpus cancer cases demonstrated the high proportion of the I/II-stage cancer: $303(81.2 \%)$ patients in the treatment group and 303 $(79.7 \%)$ patients in the control group $(p>0.05)$. That could be explained by the features of the disease clinical picture, which caused patients to consult doctors early, especially at the premenopausal and menopausal age (Table 2).

Among the ovarian cancer patiens, the patients with the III/ IV-stage disease prevailed: 96 (59.6\%) patients in the treatment group and 96 (58.9\%) people in the control group; there were no significant differences $(p>0.05)$ (Table 3 ).

The treatment group patients with cervical cancer were mainly aged 23-92, the average age was $51.6 \pm 14.2$, and the control group patients were aged $20-88$, the average age 
Table 1. Stage distribution in cervical cancer patients (C53) of the treatment and control groups according to the FIGO system (2009)

\begin{tabular}{|c|c|c|c|c|c|c|c|c|c|c|c|c|c|}
\hline \multirow{2}{*}{\multicolumn{2}{|c|}{ Groups }} & \multicolumn{12}{|c|}{ Stage of the disease } \\
\hline & & 1 & $\mathrm{~A}$ & IB & $\|$ & $\| A$ & $\| \mathrm{B}$ & III & IIIA & IIIB & IV & IVA & IV $\mathrm{B}$ \\
\hline Treatment & Abs. & 28 & 22 & 33 & 27 & 8 & 81 & 25 & 2 & 141 & 14 & 4 & 4 \\
\hline$(n-389)$ & $\%$ & 7.2 & 5.7 & 8.5 & 6.9 & 2.1 & 20.8 & 6.4 & 0.5 & 36.2 & 3.6 & 1 & 1 \\
\hline Control & Abs. & 30 & 23 & 28 & 33 & 4 & 81 & 32 & 4 & 136 & 16 & 4 & 4 \\
\hline$(n-395)$ & $\%$ & 7.6 & 5.8 & 7.1 & 8.4 & 1 & 20.5 & 8.1 & 1 & 34.4 & 4.1 & 1 & 1 \\
\hline
\end{tabular}

was $51.4 \pm 14.0(p=0.81)$. It is worth mentioning that it is the women aged 40-59 who are mainly examined in the patient examination rooms, while people aged 39 and younger make up only one fourth of the total number of the patients examined. The poor coverage of young patients with the routine checkups is reflected in a 1.5-fold increase in the cervical cancer invasive forms detection in the Chelyabinsk Region in this age group over the past 10 years.

The age of the treatment group uterine corpus cancer patients was 31-86 (average age $62.2 \pm 9.7$ ), and the age of patients in the control group was 35-85 (average age 61.9 \pm 9.7); there were no significant differences $(p=0.72)$. The highest proportion of the endometrial cancer incidence was observed in women aged 60-69 (130 (34.9\%) people in the treatment group and 136 (35.8\%) people in the control group).

The age of the treatment group ovarian cancer patients was 20-80 (average age $57.3 \pm 13.5$ ), and the age of patients in the control group was 20-83 (average age $57.1 \pm 13.0(p=0.90)$ ).

The important prognostic factor in the cancer patients' survival rate was the primary tumor morphological type which was verified is all patients of the groups compared. Statistical analysis of both groups of patients with cervical cancer, uterine corpus cancer and ovarian cancer in accordance with the main histological tumor types revealed no significant differences ( $p>0.05)$.

Based on the PBCR of the Chelyabinsk Region data, the calculation of adjusted cumulative survival parameters for patients with malignant neoplasms of the cervix, uterus and ovaries was performed for the first time, taking into account the circumstances of the cancer detection. The calculation of survival rates was carried out using the traditional methods of data analysis at the population level. To calculate the survival rate at the population level, the actuarial (dynamic) method was used, taking into account the probable life expectancy and using age-specific mortality tables for each period of the indicator calculation. The reference date was the onset of the disease (date of diagnosis), recommended for survival assessment at the population level. If the indicators of observed survival are calculated taking into account all the causes of death of the cancer patient, for which reason they are indicative, then the indicators of adjusted survival take into account the deaths of cancer patients only of the underlying disease, while those who die from intercurrent diseases are equated to those who was excluded from the observation; all indicators are expressed in\% $[11,12]$. The calculation of survival rates and their average errors was carried out using the mathematical part of the PBCR of the Chelyabinsk Region software. The differences were considered significant when $p<0.05$

\section{RESULTS}

In 2005-2017 in 27 municipal districts and 16 urban districts of the Chelyabinsk Region, 167 patient examination rooms out of 176 established were actively operating. The total number of patient examination rooms for women was 104. In addition, in municipal districts, the function of the examination rooms was assigned to feldsher-obstetric centers, which operate as the combined patient examination rooms for men and women.

The examination rooms for women are operated by the paramedical staff (feldsher, obstetrician), who has undergone special training in oncology and has the appropriate certificate, or an obstetrician-gynecologist or dermatovenerologist who has undergone advanced training in oncology (the course of at least 72 training hours). According to the requirements, the examination in the patient examination room should target the medical personnel to detect the visually detectable tumors in both male and female patients and not to carry out the selective examination of individual organs and systems.

The importance and effectiveness of this technology for secondary prevention of malignant neoplasms is associated with the following factors:

- medical care accessibility: double shift working, examination during the first visit to the medical institution, no queue and no need to book the voucher for appointment;

- strict adherence to the routing principles for patients with identified pathology and in the case of malignant neoplasm detection, transfer of the patient from hand to hand on the day of contacting a relevant specialist or oncologist with priority of examination;

- mandatory endocervical channel and cervix smears collection and subsequent sample transfer to the cytology laboratory, sample registration, as well as monitoring the number of uninformative smears.

In 2007-2017 over 5 million women $(5,136,098)$ aged over 20 attended the patient examination rooms for examination and cytological screening aimed to detect the precancerous

Table 2. Stage distribution in uterine corpus cancer patients (C54) of the treatment and control groups according to the FIGO system (2009)

\begin{tabular}{|c|c|c|c|c|c|c|c|c|c|c|c|c|c|c|}
\hline \multirow{2}{*}{\multicolumn{2}{|c|}{ Groups }} & \multicolumn{13}{|c|}{ Stage of the disease } \\
\hline & & 1 & I & $\mathrm{R}$ & II & $\| A$ & $\| B$ & III & IIA & IIB & IIIC & IV & IVA & IV B \\
\hline Treatment & Abs. & 99 & 52 & 79 & 14 & 45 & 14 & 24 & 12 & 13 & 4 & 2 & 12 & 3 \\
\hline$(n-373)$ & $\%$ & 26.5 & 13.9 & 21.2 & 3.8 & 12.1 & 3.8 & 6.4 & 3.2 & 3.5 & 1.1 & 0.5 & 3.2 & 0.8 \\
\hline Control & Abs. & 95 & 60 & 78 & 12 & 47 & 11 & 26 & 18 & 14 & 1 & 2 & 14 & 2 \\
\hline$(n-380)$ & $\%$ & 25 & 15.8 & 20.5 & 3.2 & 12.4 & 2.9 & 6.8 & 4.7 & 3.7 & 0.3 & 0.5 & 3.7 & 0.5 \\
\hline
\end{tabular}


Table 3. Stage distribution in ovarian cancer patients (C56)of the treatment and control groups according to the FIGO system (2009)

\begin{tabular}{|c|c|c|c|c|c|c|c|c|c|c|c|c|c|c|}
\hline \multirow{2}{*}{\multicolumn{2}{|c|}{ Groups }} & \multicolumn{13}{|c|}{ Stage of the disease } \\
\hline & & 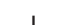 & 10 & 18 & If & & & & & 11 & & & 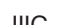 & \\
\hline Treatment & Abs. & 21 & 14 & 1 & 17 & 3 & 2 & 5 & 2 & 26 & 4 & 3 & 31 & 32 \\
\hline$(n-161)$ & $\%$ & 13 & 8.7 & 0.6 & 10.6 & 1.9 & 1.2 & 3.1 & 1.2 & 16.1 & 2.5 & 1.9 & 19.3 & 19.9 \\
\hline Control & Abs. & 21 & 16 & 1 & 16 & 4 & 2 & 6 & 1 & 25 & 3 & 3 & 34 & 31 \\
\hline$(n-163)$ & $\%$ & 12.9 & 9.8 & 0.6 & 9.8 & 2.5 & 1.2 & 3.7 & 0.6 & 15.3 & 1.8 & 1.8 & 20.9 & 19 \\
\hline
\end{tabular}

conditions, chronic diseases and malignancies (about $49.5 \%$ of women over 20 living in the region). Thus, a certain "reserve" is created out of an average of $50.5 \%$ of people who seek medical help much less than once a year, which means they cannot be fully covered by preventive measures, including examinations in the patient examination rooms.

During their work, patient examination rooms proved to be highly effective, which was reflected by the total number of actively detected the visually detectable gynecologic malignancies, but also by the total number of detected chronic and precancerous diseases. Thus, in 2017 the patient examination rooms personnel diagnosed 97,367 of all diseases in women, which was $53.7 \%$ more compared to 2007 . In the structure of the diseases detected the chronic diseases have the highest proportion: 66,805 (68.61\%) cases in 2017 , 40,106 (63.3\%) cases in 2007; the increase over the 10-year follow-up period was $66.6 \%$. The average detectability of chronic diseases (\% of the examined in the examination rooms' patients) was $11.2 \%$. In accordance with their detectability in the patient examination rooms, precancerous diseases were on the $2^{\text {nd }}$ place $(29,885(30.7 \%)$ patients in $2017,22,801(36.0 \%)$ patients in 2007; the increase over the specified period was $31.1 \%$, the average detectability for the region was $5.9 \%$ of the examined patients number). Malignant neoplasms were on the 3rd place in accordance with the detectability in the patient examination rooms. In 2017677 cancer patients were identified (12.0 per 10,000 surveyed patients), which made up $7.5 \%$ of the total number of identified women with cancer in Chelyabinsk Region. Compared to 2007, the increase in the absolute number of identified cancer patients became 1.5 times higher (by 50.8\%).

In 2007-2017 the patients examination rooms employees identified 548 uterine corpus cancer patients (8.6\% of the total number of endometrioid cancer cases for the region), 567 cervical cancer patients (an average of $12.9 \%$ of the number of cervical cancer patients detected in the region) and 254 ovarian cancer patients $(6.4 \%$ of the total number of ovarian cancer patients in the region). The average proportion of identified I/II- stage uterine corpus cancer patients in 2010-2017 was 85.5\%, the proportion of cervical cancer patients was $50.8 \%$, and the proportion of ovarian cancer patients was $42.0 \%$, which was higher than similar indicators for the region $(82.0 \%, 46.1 \%$ and $37.4 \%$ respectively) (Fig. 1-3).

When evaluating the work of the patient examination rooms, much attention was paid to the indicators of the workload, which were calculated based on the regulated length of the examination room working day (7 hours (shift), examination of four patients per hour, 252 working days per year).

In 2007, at the beginning of the examination rooms' work, the workload reached $51.4 \%$. Starting from 2009, due to the opening of a number of new patient examination rooms, the workload increase was noted up to $77.9 \%$ in 2017 . We calculated the possible number of identified cancer patients under ideal conditions (100\% loading of patient examination rooms). The data obtained allowed us to conclude that with a full load of patient examination rooms for women in the region during 2007-2017 another 3,438 cancer patients would be identified instead of 6,876 , i.e., $50.0 \%$ higher than the baseline. Of them, the number of $1 /$ II-stage cancer patients would be 7,448 instead of 4,986. The method of least squares was used to approximate direct relationship between the number of examined patients and the number of cancer patients identified in the patient examination rooms of the Chelyabinsk Region over the 10-year observation period. The determination coefficient was 0.591 , which demonstrated a high correlation of the model with actual data (correlation coefficient $r=0.77 ; p=0.007$ ).

Using cytological screening, in the patient examination rooms from $79.6 \%$ women in 2007 to $94.7 \%$ women in 2017 were examined, while the coverage with cytological investigations increase towards 100\%. In 2007-2017 the total number of collected cytological smears was over 4.5 million (an average of more than 410,000 smears per year).

The most important quality criterion for evaluating the cancer prevention measures effectiveness is the cancer patients' survival rate, which also reflects the adequacy of the detected cancer staging [13].

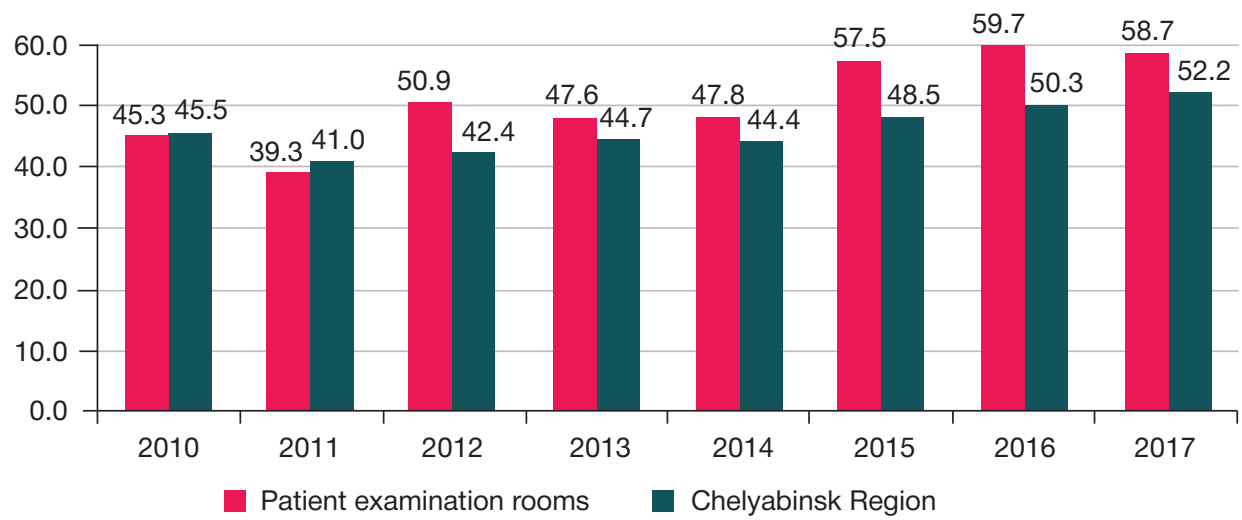

Fig. 1. Dynamics of the $\mathrm{I} / \mathrm{Il}$ stage cervical cancer (C53) proportion in patients identified actively in the patient examination rooms compared with the average rate for Chelyabinsk Region in 2010-2017, \% 
During the study, it was possible to demonstrate the advantage of the 5-year adjusted cumulative survival in cervical cancer patients identified actively in the patient examination rooms compared with the control group (62.3 versus 55.8\%) $(p=0.11)$ (Fig. 4).

In the uterine corpus cancer patients, the significant 5 -year survival rate differences were obtained: $82.0 \pm 2.6$ in the treatment group and $70.4 \pm 2.6$ in the control group $(p=0.001)$. Figure 5 demonstrates that the survival curves diverge over time.

In the ovarian cancer patients, no significant differences in the 5-year adjusted cumulative survival were detected: $47.5 \%$ in the main group and $43.2 \%$ in the control group $(p=0.49)$ (Fig. 6). Many authors agree that despite the high sensitivity of most modern diagnostic methods, their specificity is insufficient to differentiate benign and malignant processes in the ovaries, and diagnostic of each and every woman (including those not at high risk) result in minimal impact on mortality [14-16].

\section{DISCUSSION}

The improvement of the cancer early detection system should be started with the most accessible visually detectable cancer, the diagnosis of which does not require expensive diagnostic equipment and in-depth knowledge of oncology in primary health care specialists.

Despite the fact that preventive examinations play a significant role in the malignant neoplasms diagnosis, over the past 10 years in the Russian Federation, the number of patient examination rooms increased by $48 \%$ and in 2017 it reached 4989, i.e., an average of patient examination rooms for each of the 85 existing constituent regions of the Russian Federation (for instance, in 2017, in the Chelyabinsk Region the number of patient examination rooms reached 176), while the number of employees working double shifts was only $20 \%$. Insufficient coverage of the population with the routine check-ups ultimately affects the total low proportion of actively detected cancer patients $25.8 \%$ in 2017 in Russian Federation). Despite the visual localization, in 2017, the proportion of cervical cancer patients detected actively in Russia was $42.2 \%$; the proportion of uterine corpus cancer patients (29.1\% in 2017) and ovarian cancer patients (18.4\% in 2017) attending the check-ups was significantly lower. As a result, in every $2^{\text {nd }}$ and $3^{\text {rd }}$ patient in Russia, the ovarian and cervical cancer is diagnosed at the III/IV stage (58.5 and $32.4 \%$ respectively in 2017 ), which leads to low survival rates in these groups of patients, despite the number of applied treatment methods [17]. That is why there is now an urgent need for the national preventive programs aimed at the early detection and adequate treatment of preventable cancer types.

Analysis of the PBCR of the Chelyabinsk Region database for the 10-year observation period allowed us to determine, that the 5-year adjusted cumulated survival in patients with cervical cancer identified actively in the patient examination rooms appear to be more advantageous compared with the rest of the patient population (62.3 and $55.8 \%$ respectively) $(p=0.11)$. A similar trend is observed in patients with the visually undetectable tumors, such as uterine corpus cancer and ovarian cancer (82.0 versus $70.4 \%(p=0.001)$ and 47.5 versus $43.2 \%$ respectively $(p=0.49)$ ).

Such a heterogeneous group of tumors as ovarian cancer for over 30 years has been associated with slight success in long-term treatment outcome with 5-year survival rate not exceeding the $50 \%$ threshold (48.4\%) [18]. This is mainly due to the lack of reliable screening programs to date

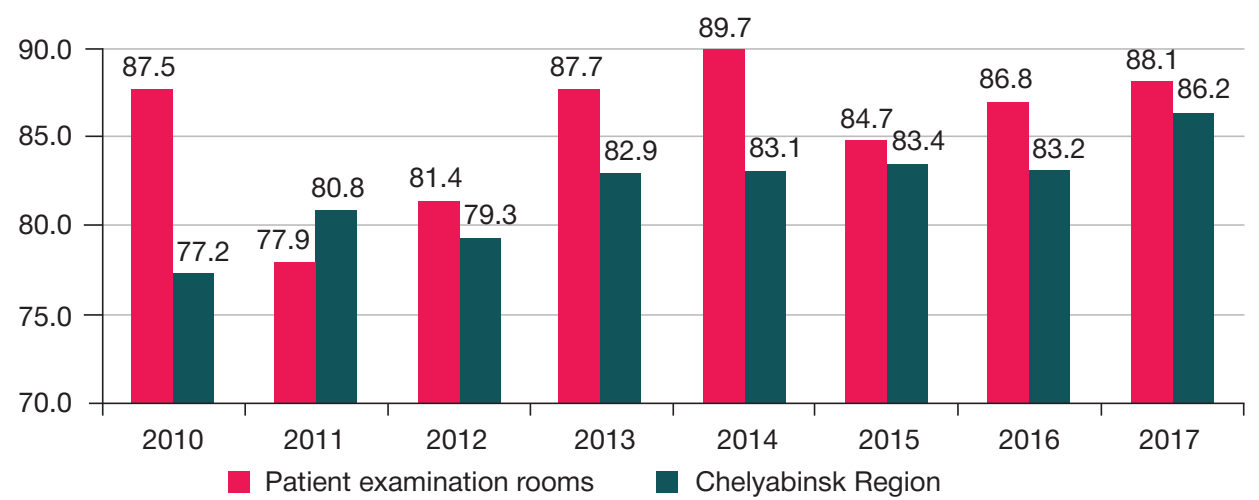

Fig. 2. Dynamics of the $\mathrm{I} / \mathrm{Il}$ stage uterine corpus cancer (C54) proportion in patients identified actively in the patient examination rooms compared with the average rate for Chelyabinsk Region in 2010-2017, \%

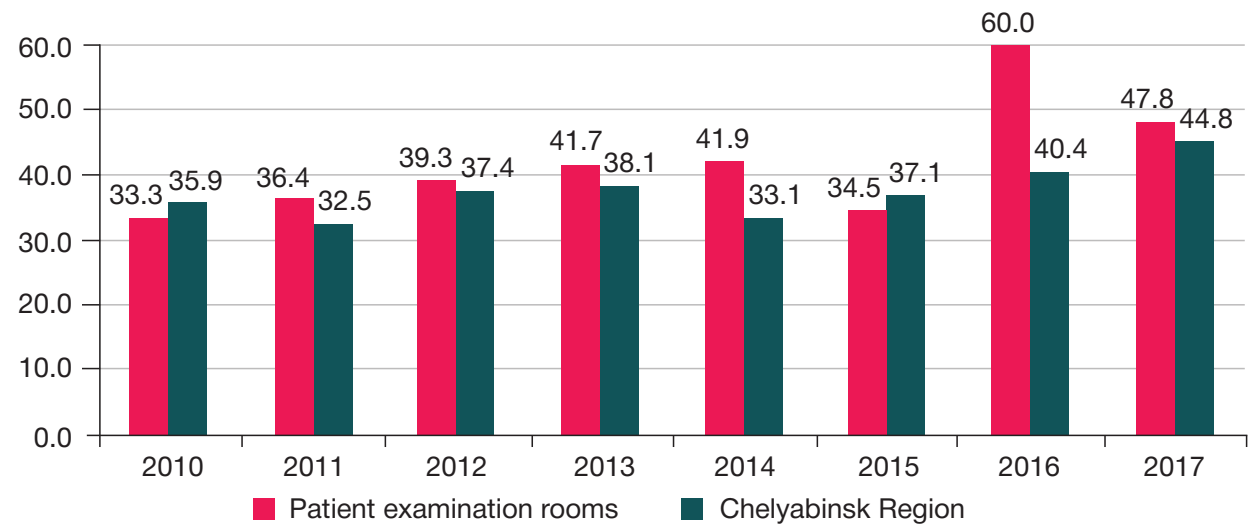

Fig. 3. Dynamics of the I/II stage ovarian cancer (C56) proportion in patients identified actively in the patient examination rooms compared with the average rate for Chelyabinsk Region in 2010-2017, \% 
allowing one to solve the problem of the ovarian cancer early diagnosis.

In general, the effectiveness of the patient examination rooms is due to the following: mass character and threading of the routine check-ups in the examination rooms (examination of at least four patients per hour throughout

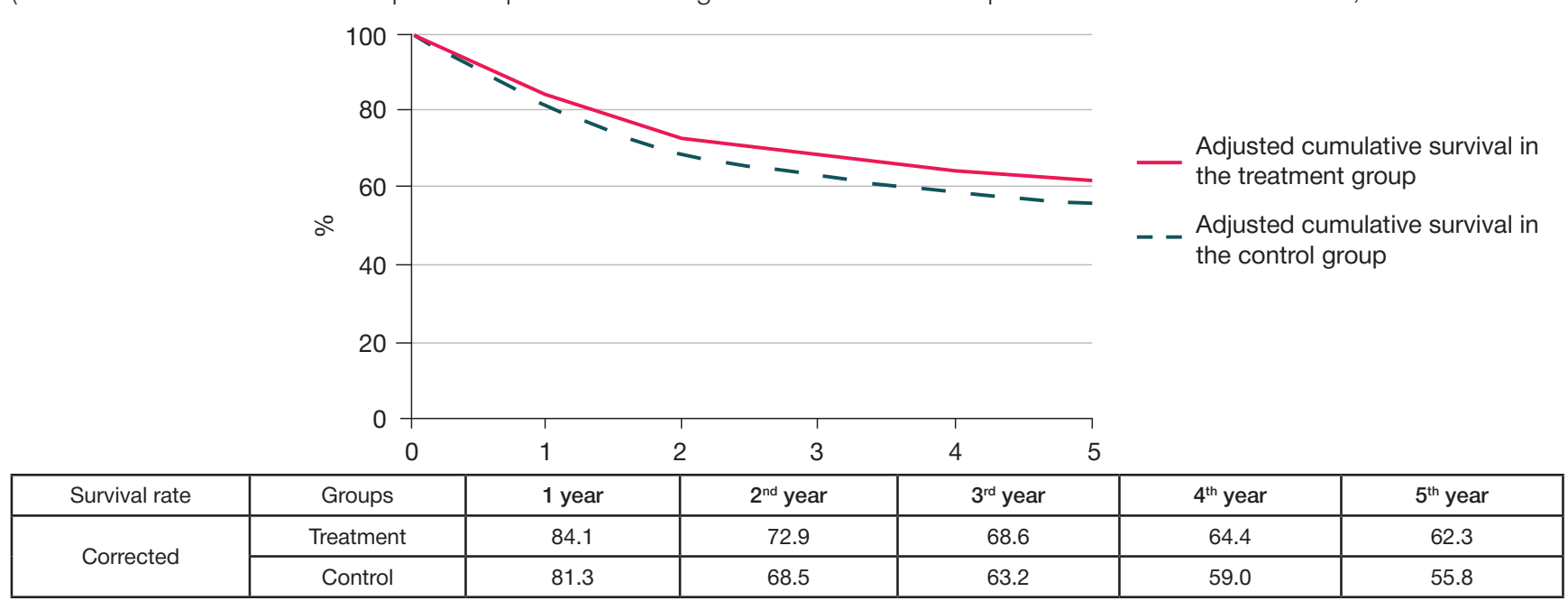

Fig. 4. Adjusted cumulative survival in cervical cancer patients (C53) of the treatment and control groups (PBCR of the Chelyabinsk Region database, 2005-2015), \%

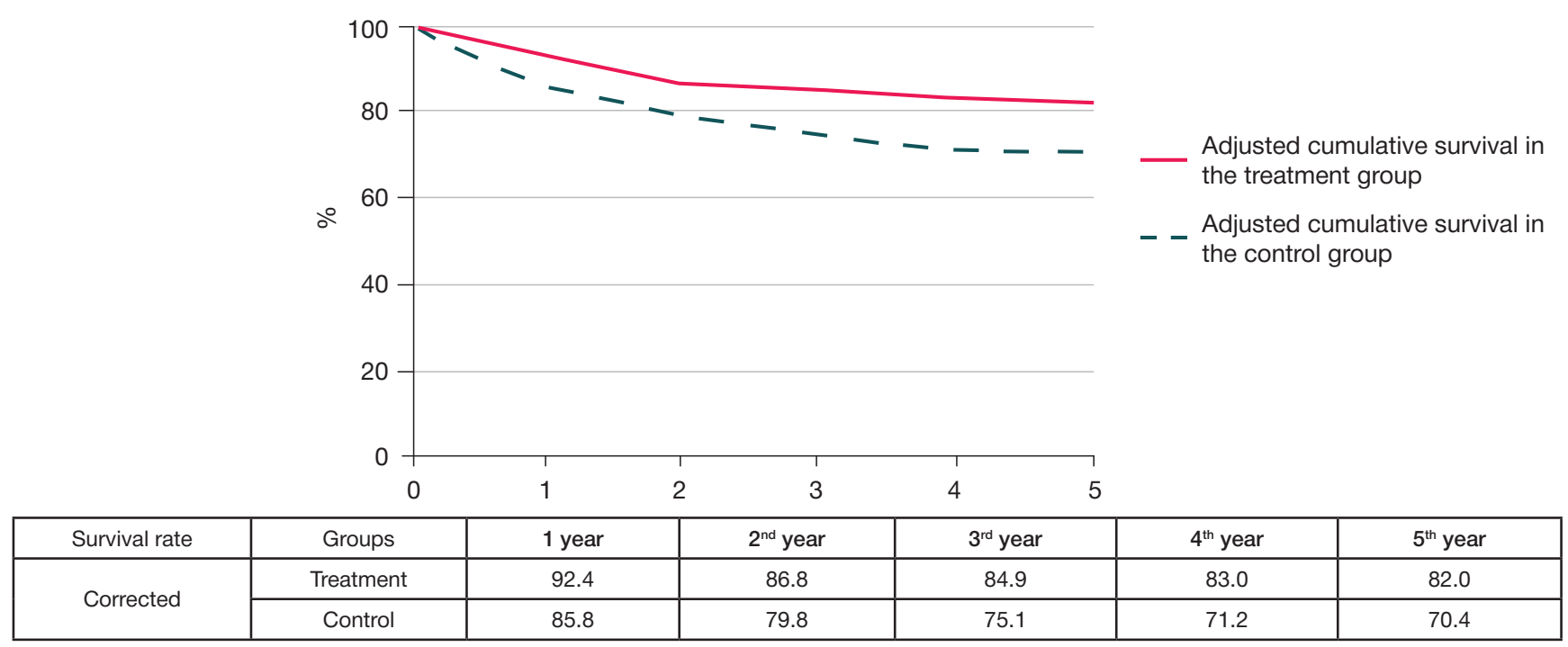

Fig. 5. Adjusted cumulative survival in uterine corpus cancer patients (C54) of the treatment and control groups (PBCR of the Chelyabinsk Region database, 2005-2015), \%

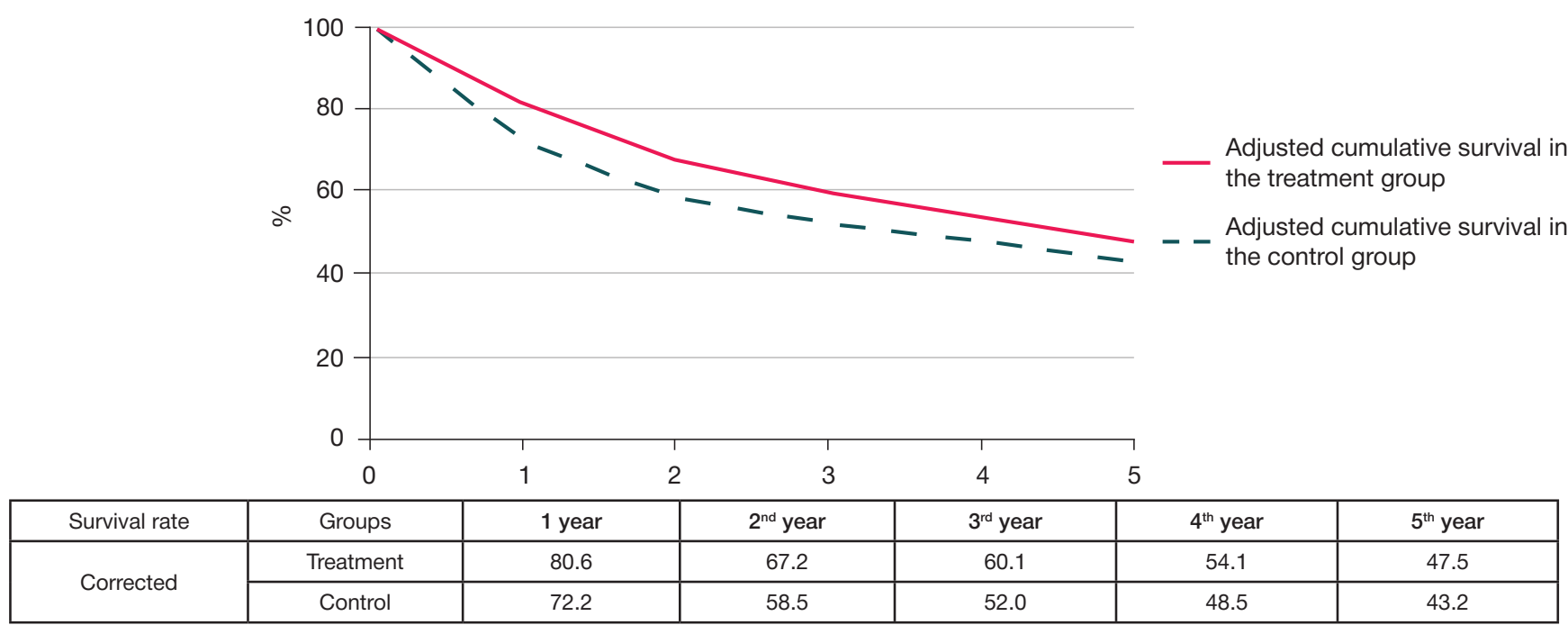

Fig. 6. Adjusted cumulative survival in ovarian cancer patients (C56) of the treatment and control groups (PBCR of the Chelyabinsk Region database, 2005-2015), \% the full working day of the clinic on a double shift basis). It is such a load that allows one to sort out the cohort of individuals with clinically non-manifesting pathology types from the total mass of the examined patients for subsequent in-depth examination. Such a task becomes impossible for a narrow specialist due to the fact that, because of the 
mentality peculiarities, the patients plan a visit to a profile specialist only with a list of specific questions inherent in the particular specialist's qualification. The work is complicated by the need of booking the voucher for appointment, which forces patients to adapt to the schedule and choose the time for the visit. While in the patient examination rooms the patients are offered to get a full examination during their first visit to the health care institution.

According to the check-up results, patients with suspected oncopathology from the very beginning attract close attention of the health care specialists and acquire the right of priority in-depth examination, while the terms of the proposed in-depth examination should fit into a strict time frame, namely 10 days from the date the diagnosis is suspected. Such patients, unlike others, without delay get into oncological institutions in case of cancer detection, which means they receive all the needed specialized oncological care in a timely manner.

\section{CONCLUSION}

Further development of programs aimed to improve the patient examination rooms' attendance in the Chelyabinsk Region, as well as the introduction of the proposed tactical algorithm in the work of the primary health care unit of the obstetric and gynecological service for the early detection of background, precancerous and malignant neoplasms, in the future will improve cancer early detection rate, and therefore minimize the costs of further treatment and rehabilitation of such patients, and, which is most important, improve the cancer patients survival rate.

\section{References}

1. Sushinskaya TV, Zhordania KI, Payanidi YuG. Analiticheskie aspekty onkologicheskikh zabolevaniy zhenskogo naseleniya Rossii. Onkoginekologiya. 2015; (3): 40-3. Russian.

2. Global Cancer Facts \& Figures. 3rd edition. Atlanta, Georgia: American Cancer Society. 2015; 61 p.

3. Kaprin AD, Starinskiy W, Petrova GV, redaktory. Zlokachestvennye novoobrazovaniya $\vee$ Rossii $v 2017$ godu (zabolevaemost' i smertnost'). M.: MNIOI im. P.A. Gertsena - filial FGBU «NMICradiologii» Minzdrava Rossii, 2018; 250 s. Russian.

4. Aleksandrova LM, Starinskiy W, Kaprin AD, Samsonov YuV. Profilaktika onkologicheskikh zabolevaniy kak osnova vzaimodeystviya onkologicheskoy sluzhby s pervichnym zvenom zdravookhraneniya. Issledovaniya i praktika v meditsine. 2017; (4): 74-80. Russian.

5. Moshurov IP, Kravets BB, Korotkikh NV. Organizatsionnye rezervy snizheniya smertnosti ot raka sheyki matki. Onkoginekologiya. 2014; (4): 28-33. Russian.

6. Krivonos OV, Chissov VI, Starinskiy VV, Aleksandrova LM. Rol'i zadachi smotrovogo kabineta polikliniki kak etapa $v$ organizatsii profilakticheskikh meropriyatiy, napravlennykh na sovershenstvovanie onkologicheskoy pomoshchi naseleniyu: metodicheskie rekomendatsii. M., 2010. Available from: http:// www.oncology.ru/service/organization/exam_room.pdf (data obrascheniya: 10.11.2019). Russian.

7. Domozhirova AS, Vazhenin AV. Vtorichnaya profilaktika raka v sisteme regional'nogo zdravookhraneniya. M.: Izd-vo RAMN, 2012; 192 s. Russian.

8. Shubin BM, Vinokur ML, Popova AA. Vyyavlenie opukholevykh zabolevaniy v smotrovom kabinete. Leningrad: Meditsina, 1980; 208 s. Russian.

9. ACOG Practice Bulletin Number 131: Screening for cervical cancer. Obstet Gynecol. 2012; 120 (5): 1222-38.

10. Ronco G, Anttila A. Cervical cancer screening in Europe changes over the last 9 years. Eur J Cancer. 2009; 45 (15): 2629-31. DOI: 10.1016/j.ejca.2009.07.021.

11. Petrova GV, Grecova OP, Kaprin AD, Starinskii W. Harakteristika i metody rascheta mediko-statisticheskih pokazatelej, primenyaemyh v onkologii. M.: FGBU MNIOI im. P.A. Gercena Minzdrava RF, 2014; 40 s.

12. Merabishvili VM. Onkologicheskaya statistika (tradicionnye metody, novye informacionnye tekhnologii): Rukovodstvo dlya vrachej. Izd. 2-e, dop. SPb., 2015; 248 s.

13. Merabishvili VM. Vyzhivaemost' onkologicheskih bol'nyh. SPb., 2011; 329 s.

14. Urmancheeva AF, Kutusheva GF, Ul'rih EA. Opuholi yaichnika (Klinika, diagnostika i lechenie). SPb.: Izd-vo N-L, 2012; 68 s.

15. Jacobs IJ, Menon U, Ryan A, Gentry-Maharaj A, Burnell $M$, Kalsi JK, et al. Ovarian cancer screening and mortality in the UK Collaborative Trial of Ovarian Cancer Screening (UKCTOCS): a randomised controlled trial. Lancet. 2016; 387 (10022): 945-56. PubMed PMID: 26707054.

16. Johnson $\mathrm{N}$. Two large randomised trials show ovarian cancer screening has minimal impact on survival. BJOG. 2016; 125 (5): $524-5$.

17. Kaprin AD, Starinskij W, Petrova GV, redaktory. Sostoyanie onkologicheskoj pomoshchi naseleniyu Rossii v 2017 godu. M. MNIOI im. P.A. Gercena - filial FGBU «NMICradiologii» Minzdrava Rossii, 2018; $236 \mathrm{~s}$.

18. Howlader N, Noone AM, Krapcho M, Miller D, Brest A, Yu M, et al. SEER Cancer Statistics Review, 1975-2016, National Cancer Institute. Bethesda, MD. Available from: https://seer.cancer.gov/ csr/1975_2016/sections.html.

\section{Литература}

1. Сушинская Т. В., Жорданиа К. И., Паяниди Ю.Г. Аналитические аспекты онкологических заболеваний женского населения России. Онкогинекология. 2015; (3): 40-3.

2. Global Cancer Facts \& Figures. 3rd edition. Atlanta, Georgia: American Cancer Society. 2015; 61 p.

3. Каприн А. Д., Старинский В. В., Петрова Г. В., редакторы. Злокачественные новообразования в России в 2017 году (заболеваемость и смертность). М.: МНИОИ им. П. А. Герцена филиал ФГБУ «НМИЦрадиологии» Минздрава России, 2018; 250 c.

4. Александрова Л. М., Старинский В. В., Каприн А. Д., Самсонов Ю. В. Профилактика онкологических заболеваний как основа взаимодействия онкологической службы с первичным звеном здравоохранения. Исследования и

практика в медицине. 2017; (4): 74-80.

5. Мошуров И. П., Кравец Б. Б., Коротких Н. В. Организационные резервы снижения смертности от рака шейки матки. Онкогинекология. 2014; (4): 28-33.

6. Кривонос О. В., Чиссов В. И., Старинский В. В., Александрова Л. М. Роль и задачи смотрового кабинета поликлиники как этапа в организации профилактических мероприятий, направленных на совершенствование онкологической помощи населению: методические рекомендации. М., 2010. Доступно по ссылке: http://www.oncology.ru/service/organization/exam_room.pdf (дата обращения: 10.11.2019).

7. Доможирова А. С., Важенин А. В. Вторичная профилактика рака в системе регионального здравоохранения. М.: Изд-во PAMH, 2012; 192 C. 
8. Шубин Б. М., Винокур М. Л., Попова А. А. Выявление опухолевых заболеваний в смотровом кабинете. Ленинград: Медицина, 1980; 208 с.

9. ACOG Practice Bulletin Number 131: Screening for cervical cancer. Obstet Gynecol. 2012; 120 (5): 1222-38.

10. Ronco G, Anttila A. Cervical cancer screening in Europe changes over the last 9 years. Eur J Cancer. 2009; 45 (15): 2629-31. DOl: 10.1016/j.ejca.2009.07.021.

11. Петрова Г. В., Грецова О. П., Каприн А. Д., Старинский В. В. Характеристика и методы расчета медико-статистических показателей, применяемых в онкологии. М.: ФГБУ МНИОИ им. П. А. Герцена Минздрава РФ, 2014; 40 с.

12. Мерабишвили В. М. Онкологическая статистика (традиционные методы, новые информационные технологии): Руководство для врачей. Изд. 2-е, доп. СПб., 2015; 248 с.

13. Мерабишвили В. М. Выживаемость онкологических больных СПб., 2011; 329 с.

14. Урманчеева А. Ф., Кутушева Г. Ф., Ульрих Е. А. Опухоли яичника (клиника, диагностика и лечение). СПб.: Изд-во Н-Л, 2012; 68 c

15. Jacobs IJ, Menon U, Ryan A, Gentry-Maharaj A, Burnell M, Kalsi JK, et al. Ovarian cancer screening and mortality in the UK Collaborative Trial of Ovarian Cancer Screening (UKCTOCS): a randomised controlled trial. Lancet. 2016; 387 (10022): 945-56. PubMed PMID: 26707054.

16. Johnson N. Two large randomised trials show ovarian cancer screening has minimal impact on survival. BJOG. 2016; 125 (5): 524-5.

17. Каприн А. Д., Старинский В. В., Петрова Г. В., редакторы. Состояние онкологической помощи населению России в 2017 году. М.: МНИОИ им. П.А. Герцена - филиал ФГБУ «НМИЦрадиологии» Минздрава России, 2018; 236 с.

18. Howlader N, Noone AM, Krapcho M, Miller D, Brest A, YuM, et al. SEER Cancer Statistics Review, 1975-2016, National Cancer Institute. Bethesda, MD. Available from: https://seer.cancer.gov/ csr/1975_2016/sections.html. 